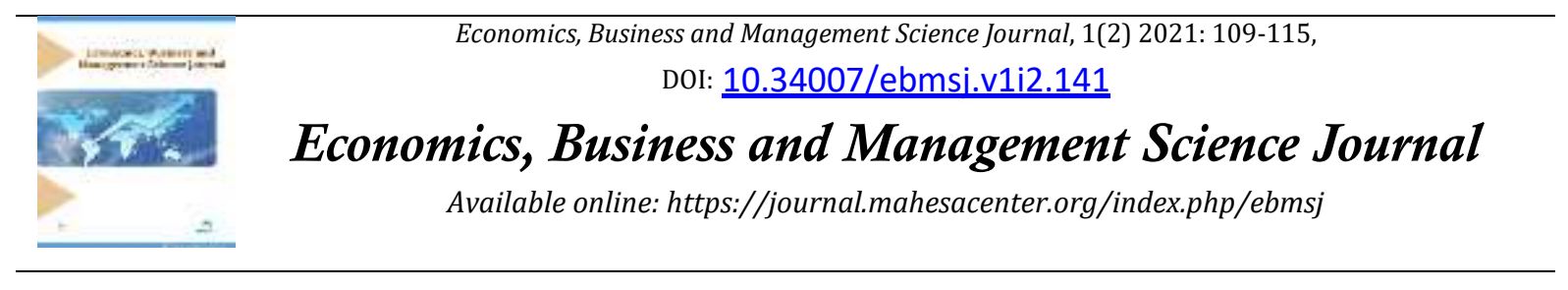

\title{
Analisis Faktor-Faktor Yang Mempengaruhi Kepuasan Konsumen Sakhi's Coffee \& Resto Di Kota Medan
}

\section{Analysis of Factors Affecting Sakhi's Coffee \& Resto's Consumer Satisfaction In Medan City}

\author{
Adelina Lubis' ${ }^{1)}$, Sari Bulan Tambunan2), \& Muslim Wijaya3) \\ 1) Prodi Manajemen Fakultas Ekonomi dan Bisnis Universitas Medan Area \\ 2) Prodi Manajemen Fakultas Ekonomi dan Bisnis Universitas Medan Area \\ 3) Prodi Akuntansi Fakultas Ekonomi dan Bisnis Universitas Medan Area
}

\begin{abstract}
Abstrak
Penelitian ini bertujuan untuk menganalisis faktor-faktor yang mempengaruhi kepuasan konsumen Sakhi's Coffee \& Resto. Sampel dalam penelitian ini adalah konsumen Sakhi's Coffee \& Resto sebanyak 100 konsumen. Teknik analisis yang digunakan dalam penelitian ini adalah analisis deskriptif dan uji regresi linear berganda.Hasil penelitian ini menunjukan bahwa variabel kualitas produk secara parsial berpengaruh positif dan signifikan terhadap kepuasan konsumen Sakhi' Coffee \& Resto, variabel kualitas pelayanan secara parsial berpengaruh positif dan signifikan terhadap kepuasan konsumen Sakhi' Coffee \& Resto, variabel harga secara parsial berpengaruh positif dan signifikan terhadap kepuasan konsumen Sakhi' Coffee \& Resto. Nilai Adjusted R Square yang diperoleh sebesar 0,363 angka tersebut menunjukkan bahwa sebesar 36,3\%. Kepuasan konsumen (variabel terikat) dapat dijelaskan oleh variabel faktor kualitas produk, kualitas pelayanan dan harga. Sisanya 63,7\% dipengaruhi oleh faktor-faktor lain yang tidak dijelaskan dalam penelitian ini.

Kata kunci: Kualitas Produk; Kualitas Pelayanan; Kepuasan Pelanggan.

Abstract

This study aims to analyze the factors that affect the consumer satisfaction of Sakhi's Coffee \& Resto. The sample in this study were 100 people Sakhi's Coffee \& Resto consumers. The analytical technique used in this study is descriptive analysis and multiple linear regression test. The results of this study indicate that the product quality variable partially has a positive and significant effect on Sakhi' Coffee \& Resto consumer satisfaction, the service quality variable partially has a positive and significant effect on customer satisfaction. Sakhi' Coffee \& Resto consumer satisfaction, the price variable partially has a positive and significant effect on Sakhi' Coffee \& Resto consumer satisfaction. The Adjusted $R$ Square value obtained is 0.363 this figure shows that it is $36.3 \%$. Consumer satisfaction (the dependent variable) can be explained by the variables of product quality, service quality and price. The remaining $63.7 \%$ is influenced by other factors not described in this study.

Keywords: Product Quality; Service Quality; Customer Satisfaction.
\end{abstract}

How to Cite: Lubis, A. Tambunan, S.B. \& Wijaya, M. (2021). Analisis Faktor-Faktor Yang Mempengaruhi Kepuasan Konsumen Sakhi's Coffee \& Resto Di Kota Medan. Economics, Business and Management Science Journal, 1(2) 2021: 109-115, 


\section{PENDAHULUAN}

Perkembangan bisnis di Kota Medan mengalami perkembangan yang sangat pesat. Gaya hidup masyarakat modern yang semakin dinamis membuat pergeseran dalam banyak hal, salah satunya dalam hal gaya hidup. Salah satu bisnis yang sedang berkembang adalah bisnis resto atau cafe. (Lestari dkk, 2020; Nabilah dkk, 2020). Keberadaan bisnis resto/cafe yang semakin bertambah menjadi bukti semakin ketatnya persaingan tersebut di wilayah kota medan (https://www.wartaekonomi.co.id/read220923/pertumbuhan-usaha-kuliner-di-medan-kianberkembang) .

Menangkap peluang ini dan pergeseran gaya hidup masyarakat yang menjadikan kegiatan tersebut sebagai bagian dari kebutuhan hidup, membuat para pelaku bisnis semakin berminat dalam mengelola usahanya. Dimana kehadiran pelaku bisnis ini dimulai yang paling sesuai dengan trend dan gaya hidup. Suasana cafe yang nyaman, pilihan menu yang berkualitas dengan harga yang terjangkau serta fasilitas yang menarik tentu merupakan alasan bagi masyarakat untuk memilih cafe sebagai tempat refreshing. (Ginting dkk, 2020; Sitepu dkk, 2020).

Dalam menghadapi lingkungan persaingan semakin kuat dan ketat, setiap perusahaan dituntut harus mampu mengoptimalkan sumber daya ekonominya guna meningkatkan daya saing produknya di pasar, serta mampu mengoptimalkan sumber daya ekonominya guna meningkatkan daya saing produknya di pasar, serta mampu meramu serangkaian strategi pemasaran yang efektif dan selalu mengembangkan strategi pemasaran tersebut secara terus-menerus serta berkelanjutan. Hal ini yang dilakukan sebagai upaya untuk meraih keunggulan bersaing. Untuk dapat bertahan dan berkembang, pengelola bisnis dituntut untuk mampu menciptakan keunggulan bersaing atas produk, pelayanan, dan harga dalam upaya memuaskan pelanggan dan menghadapi persaingan dalam bisnis. Apabila tuntutan ini tidak terpenuhi maka bisnis ini tidak akan dapat bertahan hidup. (Jonathan \& Effendi, 2020; Brahamana dkk, 2020).

Sakhi's Coffee \& Resto merupakan salah satu cafe yang ada di Kota Medan, tingkat pendapatan di Sakhi's Coffee \& Resto setiap bulan mengalami penurunan jumlah pendapatan, tabel 1 menunjukkan jumlah tingkat pendapatan Sakhi's Coffee \& Resto dari bulan Januari - Juni Tahun 2021 adalah :

Tabel 1. Jumlah Pendapatan Sakhi's Coffee \& Resto Bulan Januari-Juni 2020

\begin{tabular}{ll}
\hline Bulan & Jumlah Pendapatan \\
\hline Januari & Rp. $35 \cdot 056.000,-$ \\
\hline Februari & Rp. $31.493 \cdot 000,-$ \\
\hline Maret & Rp. $30.456 .000,-$ \\
\hline April & Rp. $32.000 .600,-$ \\
\hline Mei & Rp. 30.279.000,- \\
\hline Juni & Rp.29.537.000,- \\
\hline
\end{tabular}

Berdasarkan analisis tabel 1 dapat dinyatakan bahwa jumlah pendapatan dari Sakhi's Coffee \& Resto mengalami angka fluktuatif. Bila perusahaan bisa lebih meningkatkan kulitas produk dengan harga yang lebih terjangkau oleh para konsumen dan meningkatkan pelayanan, maka secara tidak langsung tingkat kepuasan para pelanggan akan tercapai. Dengan begitu akan lebih meningkatkan pendapatan bagi usaha itu sendiri. (Lubis, 2014; Wijaya, 2017).

Kualitas produk merupakan totalitas dan karakteristik untuk memuaskan kebutuhan, kualitas produk merupakan ketahanan suatu produk, kehandalan, ketepatan, kemudahan operasi dan perbaikan, serta atribut-atribut nilai lainnya (Kotler \& Keller, 2012). Dari sudut pandang pemasaran, kualitas harus diukur sehubungan dengan persepsi kualitas para pembeli (Hermawan, 2011). Usaha bisnis yang mampu memberikan kualitas produk yang tinggi akan lebih memberi keuntungan dibandingkan dengan kualitas produk rendah. Konsumen akan bersedia membeli asalkan kualitas produk baik. Kualitas produk merupakan salah satu pertimbangan yang penting bagi konsumen untuk membeli produk. Kualitas produk yang baik memenuhi kebutuhan dan keinginan konsumen terhadap suatu produk dalam hal ini adalah dari aneka makanan dan minuman yang ada di Sakhi's Coffee \& Resto. (Sihaloho \& Utama, 2016; Rahman dkk, 2020).

Selanjutnya menurut Parasuraman, Zeitaml, dan Berry (dalam Lovelock, 2004) terdapat lima dimensi kualitas layanan yang disebut SERVQUAL yang terdiri dari aspek-aspek TERRA, yaitu 
tangible (bukti fisik), emphaty (empati), reliability (keandalan), responsiveness (daya tanggap), dan assurance (kepastian). Sakhi' Coffee \& Resto telah menjalankan kelima aspek TERRA tersebut, namun masih banyak kekurangan dalam hal pelayanannya.

Harga juga merupakan faktor yang sangat penting karena penempatan harga dapat menjadi keunggulan strategi untuk bersaing secara efektif, tinggi rendahnya harga akan mempengaruhi tingkat penjualan (Tjiptono, 2015). Kepuasan konsumen merupakan konsep penting dalam pemasaran, kepuasan telah menjadi subjek penelitian konsumen yang dilakukan banyak usaha bisnis untuk mengetahui apakah keinginan dari konsumen. Konsumen yang puas terhadap kualitas produk, kualitas pelayanan dan harga akan memberikan keuntungan untuk usaha. Kepuasan didefinisikan sebagai tingkat perasaan seseorang setelah membandingkan kinerja atau hasil yang dirasakan dengan harapannya. Tingkat kepuasan merupakan fungsi dari perbedaan antara kinerja yang dirasakan dengan harapan. Apabila kinerja dibawah harapan, maka pelanggan akan sangat kecewa bila kinerja sesuai atau melebihi harapan, maka pelanggan akan sangat puas (Hayati \& Hakim, 2014).

Berdasarkan uraian dan penjelasan di atas, maka tujuan dalam penelitian ini adalah untuk menganalisis apakah kualitas produk, kualitas pelayanan dan harga, berpengaruh positif dan singnifikan terhadap kepuasan konsumen Sakhi' Coffee \& Resto

\section{METODE PENELITIAN}

Jenis Penelitian ini adalah pendekatan asosiatif dan kuantitatif, Penelitian ini dilakukan di Sakhi' Coffee \& Resto yang beralamatkan di Jln. Bahagia, No.12 Kota Medan. Sampel dari penelitian ini berjumlah 100 konsumen dengan kriteria sudah pernah datang lebih dari 1 kali ke Sakhi' Coffee \& Resto dan memiliki kartu member Sakhi' Coffee \& Resto. Sampel penelitian ini menggunakan seluruh jumlah populasi yaitu berjumlah 100 responden. Jenis dan sumber data yang digunakan dalam penelitian ini adalah data primer dan data sekunder. Teknik pengumpulan data menggunakan teknik library research, observation, dan daftar pertanyaan (questionnaire) dengan menggunakan daftar pertanyaan/angket.

Berikut ini kerangka konseptual dalam penelitian ini adalah :

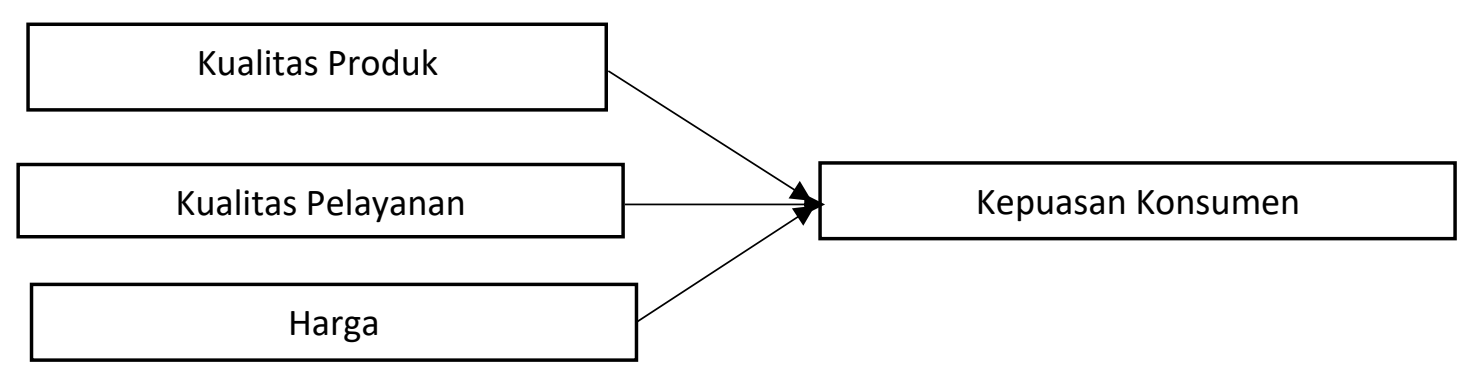

Hipotesis Penelitian :

\section{Gambar 1. Kerangka Konseptual}

1. Kualitas produk berpengaruh positif dan signifikan terhadap kepuasan konsumen Sakhi' Coffee \& Resto

2. Kualitas pelayanan berpengaruh positif dan signifikan terhadap kepuasan konsumen Sakhi' Coffee \& Resto

3. Harga berpengaruh positif dan signifikan terhadap kepuasan konsumen Sakhi' Coffee \& Resto

\section{HASIL DAN PEMBAHASAN}

Sebelum data responden diolah lebih dalam, terlebih dahulu dilakukan uji validitas dan uji reliabilitas terhadap 30 angket. Hasil dari uji validitas menyatakan bahwa hasil dari setiap indikator - indikator variabel kualitas produk, kualitas pelayanan, harga dan kepuasan pelanggan menghasilkan nilai koefisien korelasi di atas 0,361 dan nilai sig di bawah 0,05. Dari hasil tersebut dapat dinyatakan bahwa setiap pernyataan dinyatakan valid. Hasil uji reliabilitas juga menyatakan bahwa data-data yang diperoleh telah dinyatakan reliable dengan hasil cronbach's alpha di atas 0,6 . 
Adelina Lubis, Sari Bulan Tambunan, \& Muslim Wijaya, Analisis Faktor-Faktor Yang Mempengaruhi Kepuasan Konsumen Sakhi's Coffee \& Resto Di Kota Medan

\section{Analisis Deskripsti Profil Responden}

Tabel 2. Deskripsi Jenis Kelamin Responden

\begin{tabular}{lll}
\hline Jenis Kelamin & Jumlah Responden & Presentase (\%) \\
\hline Laki-Laki & 30 & $30 \%$ \\
\hline Perempuan & 70 & $70 \%$ \\
\hline & 100 & 100 \\
\hline
\end{tabular}

Berdasarkan Tabel 2 diketahui bahwa mayoritas pelanggan dari Sakhi' Coffee \& Resto adalah perempuan. Hal ini disebabkan tata letak Sakhi' Coffee \& Resto terdapat banyak kos putri, sehingga lebih banyak responden perempuan datang ke Sakhi' Coffee \& Resto karena melihat dari segi keamanan dan kenyamanan untuk mengerjakan tugas atau sekedar mengobrol tapi tidak jauh dari tempat kos.

Tabel 3 Deskripsi Usia Responden

\begin{tabular}{lll}
\hline Jenis Kelamin & Jumlah Responden & Presentase (\%) \\
\hline$<20$ Tahun & 31 & $31 \%$ \\
\hline 21-30 Tahun & 44 & $44 \%$ \\
\hline 31-40 Tahun & 15 & $15 \%$ \\
\hline$>40$ Tahun & 10 & $10 \%$ \\
\hline & 100 & 100 \\
\hline
\end{tabular}

Hasil dari Tabel 3 menggambarkan bahwa mayoritas pelanggan yang datang ke Sakhi' Coffee \& Resto masih berusia muda di bawah 30 tahun. Hal ini di sebabkan karena market dari Sakhi' Coffee \& Resto adalah anak muda, hal itu terlihat dari interior yang di tonjolkan yaitu berbentuk minimalis dan elegant membuat anak muda sering datang berkunjung.

\section{Uji Statistik}

Uji statistik menggunakan model analisis regresi linear berganda menggunakan alat bantu aplikasi Softwaren SPSS 20.00 for Windows Berdasarkan pengujian menggunakan program SPSS Statistics 22.00 for windows, maka hasil persamaan regresi linear berganda penelitian dapat dilihat pada Tabel 4 yaitu :

Tabel 4 Nilai Coefficients

Coefficients $^{a}$

\begin{tabular}{|c|c|c|c|c|c|c|c|c|}
\hline \multirow{2}{*}{\multicolumn{2}{|c|}{ Model }} & \multicolumn{2}{|c|}{$\begin{array}{l}\text { Unstandardized } \\
\text { Coefficients }\end{array}$} & \multirow{2}{*}{$\begin{array}{l}\text { Coefficients } \\
\text { Beta }\end{array}$} & \multirow[t]{2}{*}{ edT } & \multirow[t]{2}{*}{ Sig. } & \\
\hline & & $\mathrm{B}$ & Std. Error & & & & \multicolumn{2}{|c|}{$\begin{array}{l}\text { Collinearity } \\
\text { Statistics } \\
\text { Toleran ce VIF }\end{array}$} \\
\hline \multirow[t]{4}{*}{1} & (Constant) & -.270 & 2.957 & & -.125 & .901 & & \\
\hline & $\begin{array}{l}\text { Kualitas } \\
\text { Produk } \\
\end{array}$ & .128 & .101 & .170 & 2.251 & .026 & .944 & 1.059 \\
\hline & $\begin{array}{l}\text { Kualitas } \\
\text { Pelayanan }\end{array}$ & .323 & .100 & .338 & 4.230 & .000 & .844 & 1.185 \\
\hline & Harga & .249 & .058 & .339 & 4.323 & .000 & .877 & 1.140 \\
\hline
\end{tabular}

Berdasarkan Tabel 4 diperoleh model persamaan regresi linear berganda dalam penelitian ini yaitu :

$\mathrm{Y}=-270+0.128+\mathrm{X} 1+0,323 \mathrm{X} 2+0.249 \times 3$

Berdasarkan persamaan tersebut dapat diuraikan sebagai berikut :

1. Konstanta bernilai -270 menunjukkan bahwa jika tidak ada pengaruh dari variabel bebas (X1, X2 dan X3) maka kepuasan konsumen (Y) akan bernilai -270.

2. Nilai koefisien yang bertanda positif menunjukkan bahwa semakin tinggi nilai variabel bebas (X1, X2 dan X3) maka nilai kepuasan konsumen (Y) akan semakin tinggi

3. Nilai koefisien regresi yang bertanda negatif menunjukkan bahwa semakintinggi nilai variabel 
bebas (X1, X2 dan $\left.\mathrm{X}_{3}\right)$ maka nilai kepuasan konsumen $(\mathrm{Y})$ semakin rendah.

4. Koefisien $\mathrm{X}_{1}(\beta 1)=0,128$ ini menunjukkan setiap terjadi peningkatan variabel kualitas pelayanan sebesar satu satuan maka akan meningkatkan kepuasan konsumen sebesar 0,128.

5. Koefisien $\mathrm{X} 2(\beta 2)=0,323$ ini menunjukkan setiap terjadi peningkatanvariabel kepercayaan sebesar satu satuan maka akan meningkatkan kepuasan konsumen sebesar 0,323.

6. Koefisien $\mathrm{X} 3(\beta 3)=0,249$ ini menunjukkan setiap terjadi peningkatan variabel harga sebesar satu satuan maka meningkatkan kepuasan konsumen sebesar 0,249.

\section{Uji Hipotesis}

\section{a. Uji Parsial (Uji t)}

Uji t statistik dimaksudkan untuk menguji pengaruh secara parsial antara variabel bebas terhadap variabel terikat dengan asumsi bahwa variabel lain dianggap konstan, dengan tingkat keyakinan 95\% $(\alpha=0,1)$. Kriteria pengujiannya adalah : Dimana : thitung $>$ ttabel $=$ Jika variabel bebas berpengaruh terhadap variabel terikat thitung $<$ ttabel $=$ Jika variabel bebas tidak berpengaruh terhadap variabel terikat.

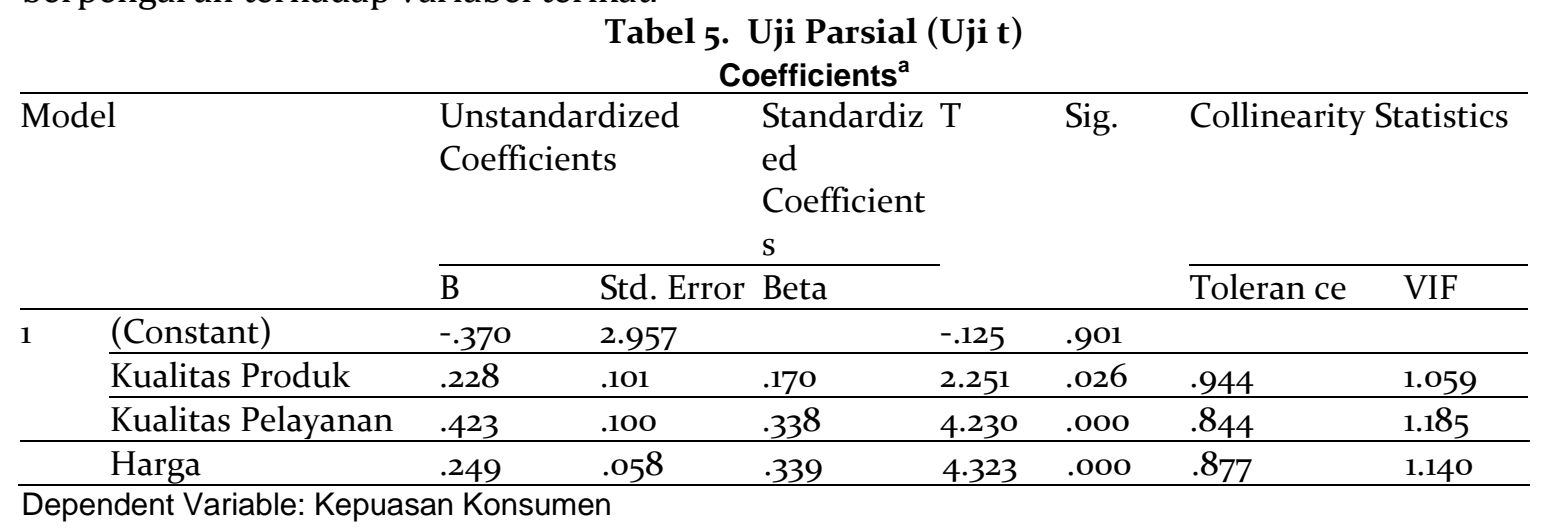

Berdasarkan hasil perhitungan SPSS diperoleh :

1. Variabel Bebas X1 (Kualitas Produk). Nilai thitung diperoleh 2,251 dimana nilai ttable pada $\alpha$ $5 \%$ yakni 1,657 artinya positif. Dimana taraf signifikan $\alpha 5 \%$ nilai thitung $2,251>$ ttable 1,657 dan nilai $p$-value pada kolom sig. 0,010<0.05 artinya signifikan. Hal ini menjelaskan bahwa kualitas pelayanan berpengaruh positif dan signifikan terhadap kepuasan konsumen pada Sakhi' Coffee \& Resto.

2. Variabel Bebas X2 (Kualitas Pelayanan). Nilai thitung diperoleh 4.230 dimana nilai ttable pada $\alpha 5 \%$ yakni 1,657 artinya positif. Dimana taraf signifikan $\alpha 5 \%$ nilai thitung $4.230>$ ttable 1,657 dan nilai $p$-value pada kolom sig. 0,000 0.05 artinya signifikan. Hal ini menjelaskan bahwa kepercayaan berpengaruh positif dan signifikan terhadap kepuasan konsumen pada Sakhi' Coffee \& Resto.

3. Variabel Bebas X3 (Harga). Nilai thitung diperoleh 4.323 dimana nilai ttable pada $\alpha 5 \%$ yakni 1,659 artinya positif. Dimana taraf signifikan $\alpha 5 \%$ nilai thitung $4.323>$ ttable 1,659 dan nilai $p$-value pada kolom sig. 0,000 $<0.05$ artinya signifikan. Hal ini menjelaskan bahwa harga berpengaruh positif dan signifikan terhadap kepuasan konsumen pada Sakhi' Coffee \& Resto.

\section{Koefisien Determinasi}

Hasil pengujian Koefisien Determinasi $\left(\mathrm{R}^{2}\right)$ adalah :

Tabel 6. Koefisien Determinasi

Model Summary ${ }^{\mathrm{b}}$

\begin{tabular}{|l|l|l|l|l|}
\hline Model & $R$ & R Square & $\begin{array}{l}\text { Adjusted } \\
\text { Square }\end{array}$ & Std. Error of the Estimate \\
\hline 1 & $.616 a$ & .379 & .363 & 2.4210 \\
\hline
\end{tabular}


Berdasarkan perhitungan koefisien determinasi, dapat dilihat nilai Adjusted R Square yang diperoleh sebesar 0,363. Angka tersebut menunjukkan bahwa sebesar 36,3\%. Kepuasan konsumen (variabel terikat) dapat dijelaskan oleh variabel faktor kualitas pelayanan dan harga. Sisanya 63,7\% dipengaruhi oleh faktor-faktor lain yang tidak dijelaskan dalam penelitian ini.

Hasil penelitian menunjukan bahwa kualitas produk berpengaruh signifikan terhadap kepuasan konsumen Sakhi' Coffee \& Resto dengan t hitung sebesar 2,251. Variabel kualitas pelayanan berpengaruh signifikan terhadap kepuasan konsumen Sakhi' Coffee \& Resto dengan $\mathrm{t}$ hitung sebesar 4,230. Variable harga berpengaruh signifikan terhadap kepuasan konsumen Sakhi' Coffee \& Resto dengan t hitung sebesar 4,323.Hal ini berarti bahwa adanya kualitas produk, kualitas layanan yang baik dan harga yang terjangkau akan memberikan pengaruh yang signifikan terhadap kepuasan konsumen di Sakhi' Coffee \& Resto. Koefisien determinasi, dapat dilihat nilai Adjusted R Square yang diperoleh sebesar 0,363. Angka tersebut menunjukkan bahwa sebesar $36,3 \%$. Kepuasan konsumen (variabel terikat) dapat dijelaskan oleh variabel faktor kualitas pelayanan dan harga. Sisanya $63,7 \%$ dipengaruhi oleh faktor-faktor lain yang tidak dijelaskan dalam penelitian ini.

Hasil ini juga didukung oleh penelitian terdahulu yang dilakukan oleh Sukmawati (2018) menyimpulkan bahwa kualitas produk, harga, dan pelayanan berpengaruh positif dan signifikan terhadap kepuasan garden Cafe koperasi mahasiswa Universitas Negeri Yogyakarta. Kemudian penelitian oleh Tjoanoto (2013) yang menyatakan bahwa kualitas layanan berpengaruh positif dan signifikan terhadap kepuasan pelanggan di restoran Jade Imperial. Penelitian yang dilakukan oleh Widjoyo dan Rumambi (2013) yang meneliti analisis pengaruh kualitas layanan terhadap kepuasan konsumen pada layanan drive thru McDonald's Basuki Rahmat Surabaya. Hasil ini juga didukung oleh penelitian yang dilakukan Aulia (2017) menyatakan bahwa ada pengaruh positif dan signifikan kualitas produk, kualitas pelayanan dan harga terhadap kepuasan konsumen Amanda Brownies.

\section{SIMPULAN}

Berdasarkan data yang diperoleh dan hasil pengelolahan data dalam penelitian, maka variabel kualitas produk secara parsial berpengaruh positif dan signifikan terhadap kepuasan konsumen Sakhi' Coffee \& Resto; Variabel kualitas pelayanan secara parsial berpengaruh positif dan signifikan terhadap kepuasan konsumen Sakhi' Coffee \& Resto; Variable harga secara parsial berpengaruh positif dan signifikan terhadap kepuasan konsumen Sakhi' Coffee \& Resto; Nilai Adjusted R Square yang diperoleh sebesar 0,363 angka tersebut menunjukkan bahwa sebesar $36,3 \%$. Kepuasan konsumen (variabel terikat) dapat dijelaskan oleh variabel kualitas produk, kualitas pelayanan dan harga. Sisanya 63,7\% dipengaruhi oleh faktor-faktor lain yang tidak dijelaskan dalam penelitian ini.

\section{DAFTAR PUSTAKA}

Aulia, M., \& Hidayat, I. (2017). Pengaruh Kualitas Produk, Kualitas Pelayanan Dan Harga Terhadap Kepuasan Konsumen Amanda Brownies. Ilmu dan Riset Manejemen , 6 (5).

Br Sitepu, A., Effendi, I., \& Tarigan, E. (2020). Analisis Risiko Investasi terhadap Return Saham pada Sub Sektor Makanan dan Minuman di Bursa Efek Indonesia. Jurnal Ilmiah Manajemen dan Bisnis (JIMBI), $1(2)$.

Br. Ginting, S., Effendi, I., \& Amelia, W. (2020). PENGARUH SERVICE DAN PROMOSI TERHADAP KEPUASAN NASABAH PADA TRUST SEBAGAI VARIABEL INTERVENING DI BPR LAKSANA ABADI SUNGGAL. Jurnal Ilmiah Manajemen dan Bisnis (JIMBI), 1(2).

Brahamana, N., Miftahuddin, M., \& Prayudi, A. (2020). Analisis Profitabilitas Dalam Pemberian Kredit Pada Koperasi Kredit Unam Berastagi. Jurnal Ilmiah Manajemen dan Bisnis (JIMBI), 1(1), 131-140

Fandy Tjiptono. 2015. Strategi Pemasaran. Edisi 4: Andi

Hayati, Y.H., \& Hakim, A.L. (2014). Pengaruh Diskriminasi Harga Terhadap Peningkatan Penjualan Kartu Perdana IM3 Pada PT. Nusapro Telemedia Persada Bogor. JIMFE (Jurnal Ilmiah Fakultas Ekonomi) $1(2), 58-67$.

Hermawan, B. (2011). Pengaruh Kualitas Produk Terhadap Kepuasan, Reputasi Merek dan Loyalitas https://www.wartaekonomi.co.id/read220923/pertumbuhan-usaha-kuliner-di-medan-kian-berkembang 
Jonathan, D., \& Effendi, I. (2020). ANALISIS PENGGELOLAAN KAS DALAM UPAYA MENJAGA TINGKAT LIKUIDITAS PERUSAHAAN BONGKAR MUAT (PBM) PT. TAO ABADI JAYA JAKARTA PERIODE TAHUN 2011-2016. Jurnal Ilmiah Manajemen dan Bisnis (JIMBI), 1(1), 41-50

Konsumen Jamu Tolak Angin PT. Sido Muncul. Jurnal Manajemen Teori Dan Terapan (2), 9-17

Kotler, Philip \& Keller, K.L., 2012. Marketing Management. 14 Ed. Prentice Hall

Lestari, M., Nasution, A., \& Lubis, A. (2020). Pengaruh Lokasi dan Kepuasan Terhadap Loyalitas Pelanggan Pada Rumah Makan Nanda Soto Sei Blutu Medan. Jurnal Ilmiah Manajemen dan Bisnis (JIMBI), 1(1), 121-130

Lovelock, Christopher \& Jochen Wirtz. (2004). Service marketing 5th edition people, technology, strategy. New York : Pearson.

LUBIS, A. (2014). PENGARUH KUALITAS PELAYANAN PENDIDIKAN TERHADAP KEPUASAN DAN LOYALITAS PADA MAHASISWA FAKULTAS EKONOMI UNIVERSITAS MEDAN AREA MEDAN. JKBM (JURNAL KONSEP BISNIS DAN MANAJEMEN), $1(1), \quad$ 29-36. doi:https://doi.org/10.31289/jkbm.v1i1.1398

Nabilah, S., Lubis, A., \& Tarigan, E. (2020). PENGARUH STRATEGI BAURAN PEMASARAN TERHADAP KEPUASAN KONSUMEN PADA AROMA BAKERY \& CAKE MEDAN. Jurnal Ilmiah Manajemen dan Bisnis (JIMBI), 1(1), 181-190

Rahman, A., Fathorrahman, F., \& Karnawati, T. (2020). Pengaruh Kepuasan Kerja, Praktik Sumber Daya Manusia dan Pasar Tenaga Kerja terhadap Keinginan Pindah Kerja Karyawan. JKBM (JURNAL KONSEP BISNIS DAN MANAJEMEN), 6(2), 164-178. doi:https://doi.org/10.31289/jkbm.v6i2.3553

Sihaloho, S., \& Utama, A. (2016). PENGARUH STRATEGI PROMOSI TERHADAP KEPUTUSAN PEMBELIAN KONSUMEN PADA CARREFOUR CITRA GARDEN MEDAN. JURNAL AKUNTANSI DAN BISNIS : Jurnal Program Studi Akuntansi, 2(2). doi:https://doi.org/10.31289/jab.v2i2.249

Sukmawati, R. (2018). Pengaruh Kualitas Produk, Harga, Dan Kualitas Pelayanan Terhadap Kepuasan Konsumen Garden Cafe Koperasi Mahasiswa Universitas Negeri Yogyakarta. Pendidikan dan Ekonomi 7 (2).

Tjoanoto. (2013). Pengaruh service quality terhadap customer satiffaction di restoran jade imperial. Jurnal Manajemen Pemasaran Petra. 3 (1). 8

Widjoyo \& Rumambi. (2013). Analisa pengaruh kualitas layanan terhadap kepuasan konsumen pada layanan drive thru McDonald's Basuki Rahmat di Surabaya. Jurnal Manajemen Pemasaran. 1(1). 10.

Wijaya, M. (2017). PENGARUH SISTEM REKRUTMEN DAN PENGEMBANGAN KARIR TERHADAP KEPUASAN KERJA KARYAWAN PADA PT. KIMIA FARMA PLANT MEDAN. JKBM (JURNAL KONSEP BISNIS DAN MANAJEMEN), 3(2), 123-130. doi:https://doi.org/10.31289/jkbm.v3i2.417 